\title{
Clinical genetics and pathobiology of ciliary chondrodysplasias
}

\author{
Miriam Schmidts ${ }^{\mathrm{a}, \mathrm{b}, *}$ \\ ${ }^{a}$ Center for Pediatrics and Adolescent Medicine, University Hospital Freiburg, Freiburg, Germany \\ ${ }^{\mathrm{b}}$ Genetics and Genomics Medicine, Institute of Child Health, University College London, London, UK
}

Received 10 June 2014

Revised 4 July 2014

Accepted 8 July 2014

\begin{abstract}
Ciliary chondrodysplasias represent a heterogenous group of rare, nearly exclusively autosomal recessively inherited developmental conditions. While the skeletal phenotype, mainly affecting limbs, ribs and sometimes the craniofacial skeleton, is predominant, extraskeletal disease affecting the kidneys, liver, heart, eyes and other organs and tissues is observed inconsistently. Significant lethality, resulting from cardiorespiratory failure due to thoracic constriction as well as from renal and hepatic insufficiency or primary cardiac failure due to congenital heart disease, is observed with these conditions. The underlying genetic defects as well as developmental biology and cell biology work undertaken using animal model systems, suggest that these rare conditions result from ciliary malfunction. The skeletal phenotype is believed to result from imbalances in the hedgehog signaling pathway that normally occurs in functional cilia in chondrocytes. Although phenotypes have been historically distinguished based on clinical features into short-rib polydactyly syndrome, Jeune asphyxiating thoracic dystrophy, MainzerSaldino syndrome, Sensenbrenner syndrome (cranioectodermal dysplasia), oral-facial-digital syndrome and Ellis-van Creveld syndrome, recent research suggests that there is significant genetic as well as phenotypic overlap between the conditions. This review discusses ciliary chondrodysplasias from phenotypic hallmarks to clinical management and summarizes progress in identification of the underlying molecular mechanisms as well as potential future therapeutic perspectives.
\end{abstract}

Keywords: Cilia, chondrodysplasia, Jeune syndrome, short-rib polydactyly syndrome, Sensenbrenner syndrome

\section{Introduction}

The term "ciliary chondrodysplasias" summarizes inherited conditions resulting from cilia malfunction affecting skeletal development in mammals. Estimated disease frequencies are 1 in 200,000 [1] to more than $1,000,000$ in western populations [2], but can be higher in genetically isolated populations [3]. However, as no large patient studies have been performed, no exact numbers are available.

\footnotetext{
*Corresponding author: Dr. Miriam Schmidts, MD, University Hospital Freiburg, Mathildenstrasse 1, 79112 Freiburg, Germany. Tel.: +447915550317; E-mails: miriam.schmidts@uniklinikfreiburg.de, miriam.schmidts.10@ucl.ac.uk.
}

Cilia are hair-like organelles projecting from the surface of cells and can be divided into two main subgroups: motile cilia, occurring in bundles of hundreds and single non-motile (primary) cilia. While the presence of motile cilia is restricted to highly specialized tissues such as the respiratory tract, brain ventricles, reproductive tract and embryonic node in mammals, primary cilia can be found on nearly every cell throughout the organism. Each cilium contains nine pairs of microtubules $(9+0$ structure) and a 10 th pair, the so-called central pair, is additionally present in motile cilia $(9+2$ structure). These motile cilia also contain other proteins necessary for the motile apparatus such as dynein arms and radial spokes not 


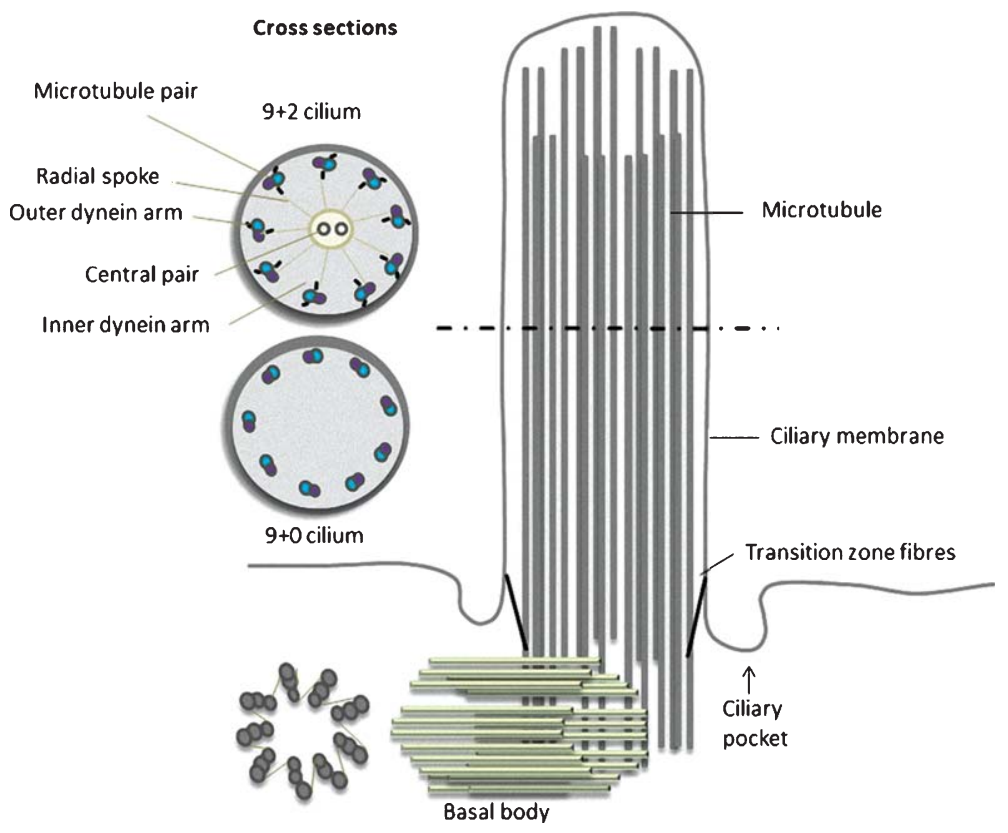

Fig. 1. Schematic of the ciliary ultrastructure. Primary cilia consist of nine pairs of microtubules, while motile cilia display an additional central pair as shown in the cross-sections. The ciliary axoneme extends from the basal body, the former mother centriole of the cell, and is covered by ciliary membrane. Transition zone fibers connect ciliary membrane with the cilium and are thought to form a barrier towards the cellular cytoplasm. The ciliary pocket has been identified as a hub for cell signaling pathways and it is thought that proteins produced within the cell body are transported to the ciliary pocket within vesicles.

observed in primary cilia. Figure 1 depicts a simplified schematic of the ciliary ultrastructure. The main function of motile cilia is fluid movement and mucociliary clearance. Defects in genes encoding for proteins of the motile apparatus lead to a cystic fibrosislike disease named primary ciliary dyskinesia (PCD; MIM 244400). Roughly, half of individuals affected by PCD present with laterality defects, which are due to impaired motile ciliary function in the embryonic node [4]. Laterality defects can also occur in non-motile ciliopathies, usually in combination with many other features. Over the past two decades, an increasing number of human genetic conditions have been linked to malfunction of primary cilia, such as polycystic kidney disease (MIM 173900, MIM 613095, MIM 236200), nephronophthisis (NPHP; MIM 256100), Joubert syndrome (MIM 213300), Bardet-Biedl syndrome (MIM 209900), Alström syndrome (MIM 203800) and the ciliary chondrodysplasias, which are highlighted in this review [5].

Ciliary chondrodysplasias represent a group of phenotypically and genetically related disorders inherited in an autosomal recessive fashion including short-rib polydactyly syndromes, which are also referred to as short-rib thoracic dystrophy (SRPS; MIM 611263, MIM 613091, MIM 263520, MIM 269860, MIM 614091), Jeune asphyxiating thoracic dystrophy or Jeune syndrome (JATD; MIM 208500), Mainzer-Saldino syndrome (MZSDS; MIM 266920), Sensenbrenner syndrome or cranio-ectodermal dysplasia (CED; MIM 218330), oral-facial-digital syndrome 4 (OFD4; MIM 258860) and Ellis-van Creveld syndrome (EVC; MIM 225500). An exception from this inheritance pattern is Weyers acrodental dysostosis (WAD; MIM 193530), which is caused by heterozygous mutations in the EVC genes. Recently, ciliary chondrodysplasias with narrow thorax and polydactyly such as SRPS and JATD have also been summarized under the term short-rib thoracic dystrophy (SRTD). However, the current SRTD classification in MIM takes only into account the underlying genetic cause while the former SRPS and JATD classification was based on phenotypic features. This can be confusing, therefore in this review I will relate to the previous established clinical classification of ciliary chondrodysplasias. Clinical hallmarks of the ciliary chondrodysplasia group include shortened limbs and ribs, polydactyly and sometimes craniofacial 
malformations such as craniosynostosis. Renal, liver, eye, heart and other organ involvement may be additionally present and phenotype severity varies significantly between the different conditions, but also between patients with the same condition [6]. The most severe thoracic constriction is usually seen in SRPS and JATD. The thoracic phenotype in SRPS is not compatible with life beyond the early neonatal age due to cardiorespiratory failure, while approximately $40 \%$ of affected individuals with JATD survive into adulthood after a period of intensive care and threat of cardiopulmonary arrest during infancy [7]. In contrast to SRPS and JATD, individuals with MZSDS and CED usually display a much milder rib phenotype, but frequently develop extraskeletal symptoms such as childhood onset end-stage renal disease, liver disease and retinal degeneration [8]. CED and EVC further lead to additional ectodermal defects such as dysplastic finger and toenails, hair and teeth abnormalities [9]. Finally, EVC is frequently associated with congenital heart anomalies such as primary atrial septation defects $[10,11]$. A complete overview of ciliary chondrodysplasias is shown in Table 1.

In contrast to PCD where lack of ciliary motility leads to the impaired fluid movement, disease mechanisms for non-motile ciliopathies are less well understood. However, the skeletal phenotype including polydactyly, observed in numerous ciliopathies in humans and mice, gave an early clue that defective hedgehog signaling might play a role. In this review, the clinical features, progress in gene identification over the last years, clinical management and future prospects regarding ciliary chondrodysplasias will be described.

\section{Clinical features of ciliary chondrodysplasias}

As briefly described above, extensive phenotypic overlap is observed between different conditions of the ciliary chondrodysplasias disease spectrum, so that clinical diagnosis can be difficult to make, especially in fetal cases. Radiographs of the skeleton play a crucial role, but even for experts it may be difficult to distinguish between the different forms [12]. This might appear arbitrary, however, making a precise diagnosis may help to predict the clinical course: SRPS are always lethal [6], MZSDS and CED have a milder rib phenotype but higher rate of renal, retinal and liver disease than classical JATD [8, 13-15] while in
EVC, severe heart defects are most frequent $[10,16]$. Nevertheless, knowing the underlying genetic defect might represent a more suitable prediction tool for disease severity and phenotypic features than applying a clinical disease term. Further, identification of the causative gene improves opportunities for genetic counseling.

\subsection{Phenotypic spectrum of perinatal lethal SPRS}

The phenotypic SRPS disease group consists of SRPS I-V, but JATD could be considered as the mild end of the spectrum: while polydactyly is a consistent feature of SRPS, it is rarely observed in JATD and the rib phenotype is usually milder in JATD accounting for reduced lethality compared to SRPS. Further, while extraskeletal malformations of the brain, heart, kidneys, liver and pancreas can be frequently observed in SRPS in prenatal ultrasound examinations, this is usually not the case for JATD. Five subtypes of SRPS are phenotypically distinguished: SRPS-I (Saldino-Noonan type; MIM 613091 [17]; SRPS-II (Majewski type; MIM 263520 [18], SRPS-III (Verma-Naumoff type; MIM 613091 [19], SRPS-IV (Beemer-Langer type; MIM 269860 [20] and SRPSV (MIM 614091 [21]). Typical clinical SRPS features are displayed in Fig. 2.

\subsubsection{SRPS-I and SRPS-III}

Similar to SRPS-II and IV, polydactyly, hydropic appearance and small thorax with short horizontal ribs causing cardiorespiratory lethality, is observed in SRPS-I. However, the typical hallmark of SRPS-I is extreme micromelia resulting in 'flipper-like' limbs [17]. Ossification defects of the vertebrae, pelvis, as well as of the bones of the hands and feet are also frequently observed. Pelvis anomalies include small ilia with flattened acetabular roofs with ossified spurs, resembling the pelvis configuration in EVC and JATD. Polycystic kidneys, transposition of the great vessels as well as atretic lesions of the gastrointestinal and genitourinary systems are reported extraskeletal features [22-24]. SRPS-III shares the typical features of SRPS such as hydropic appearance at birth, short long bones, short horizontal ribs, narrow thorax and protuberant abdomen, but is additionally characterized by a short cranial base, bulging forehead, depressed nasal bridge and flat occiput [19]. Radiologically, the long tubular bones show a corticomedullary demarcation, slightly widened metaphyses and marked longitudinal 


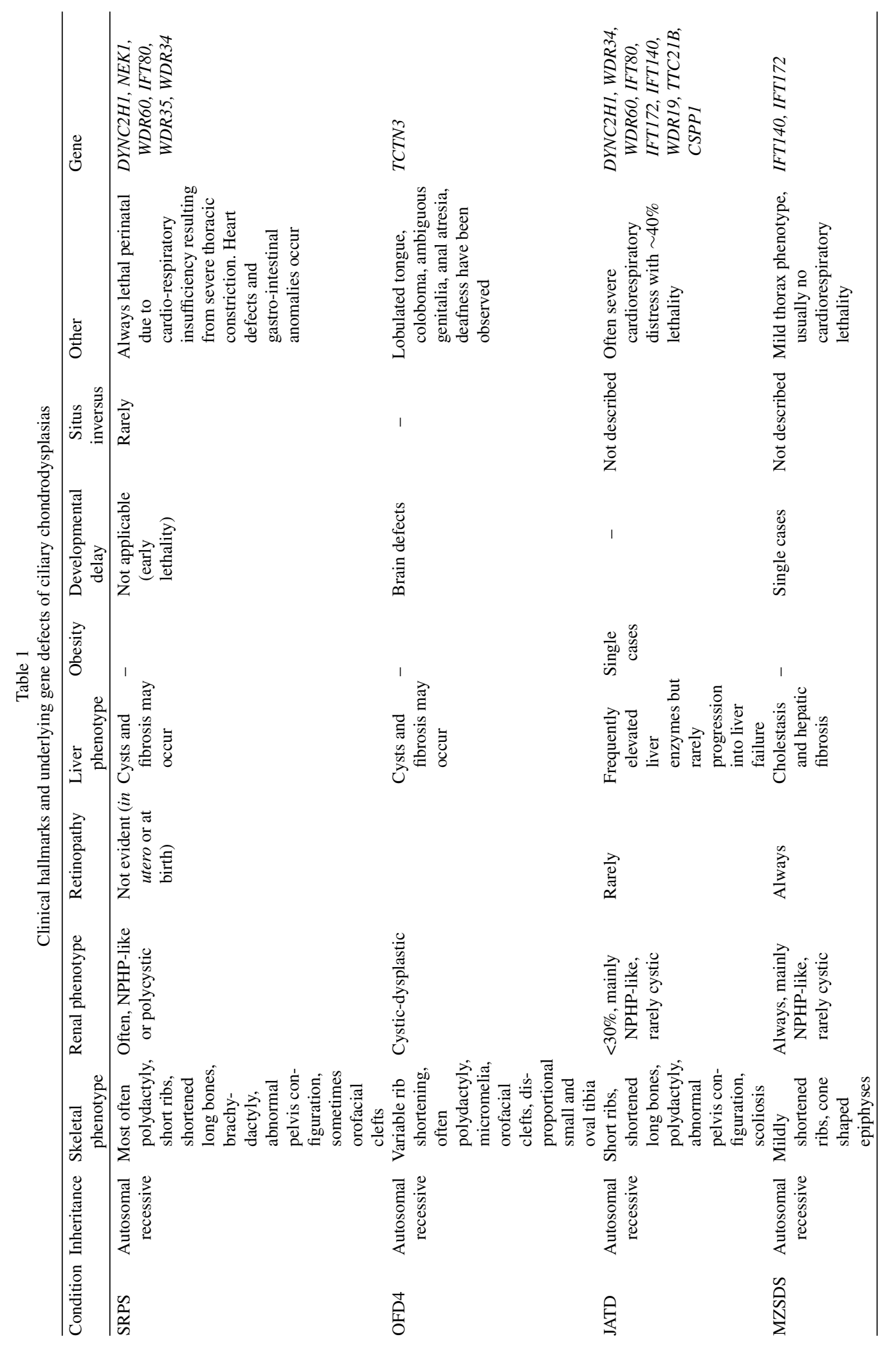




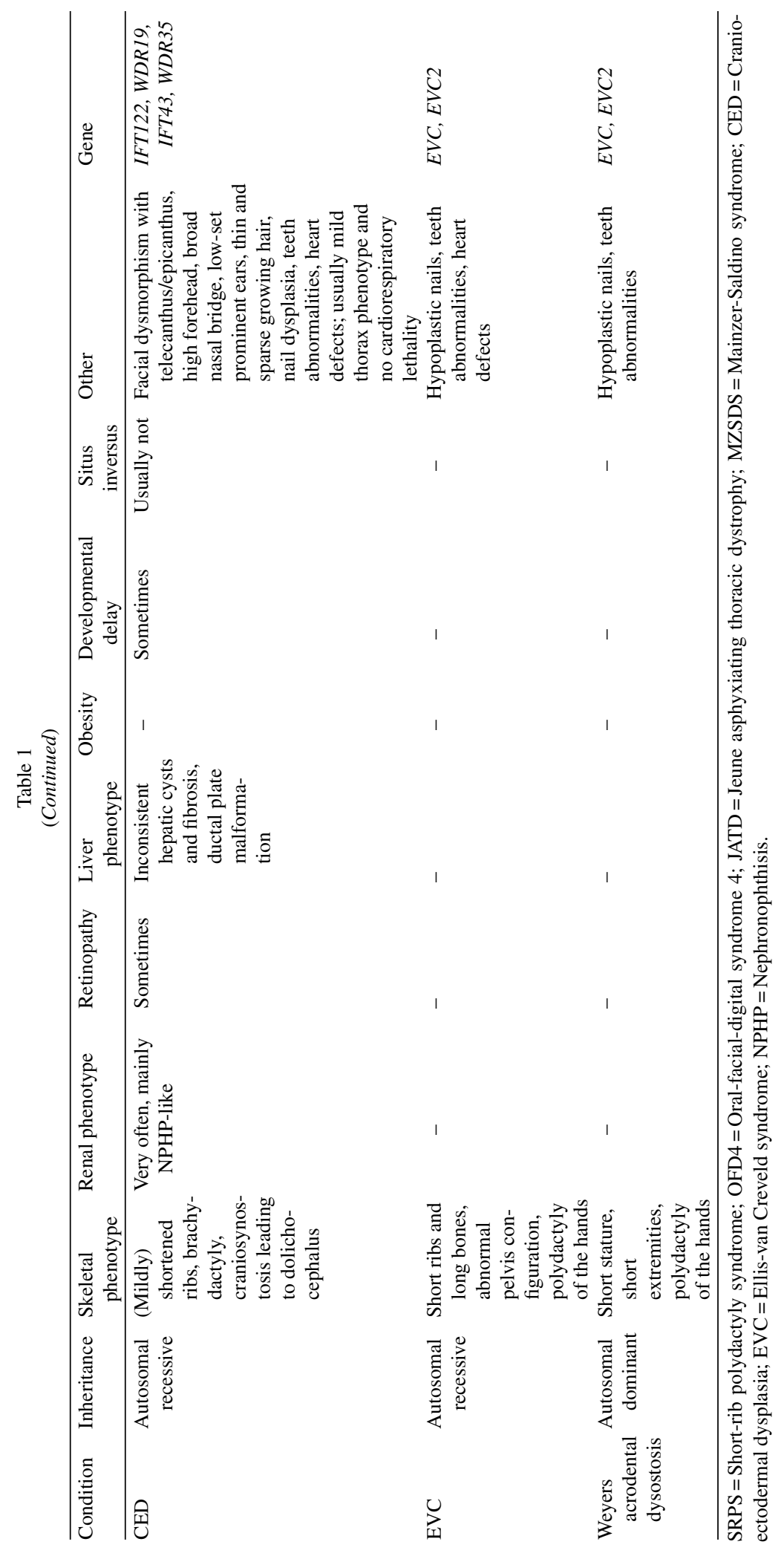



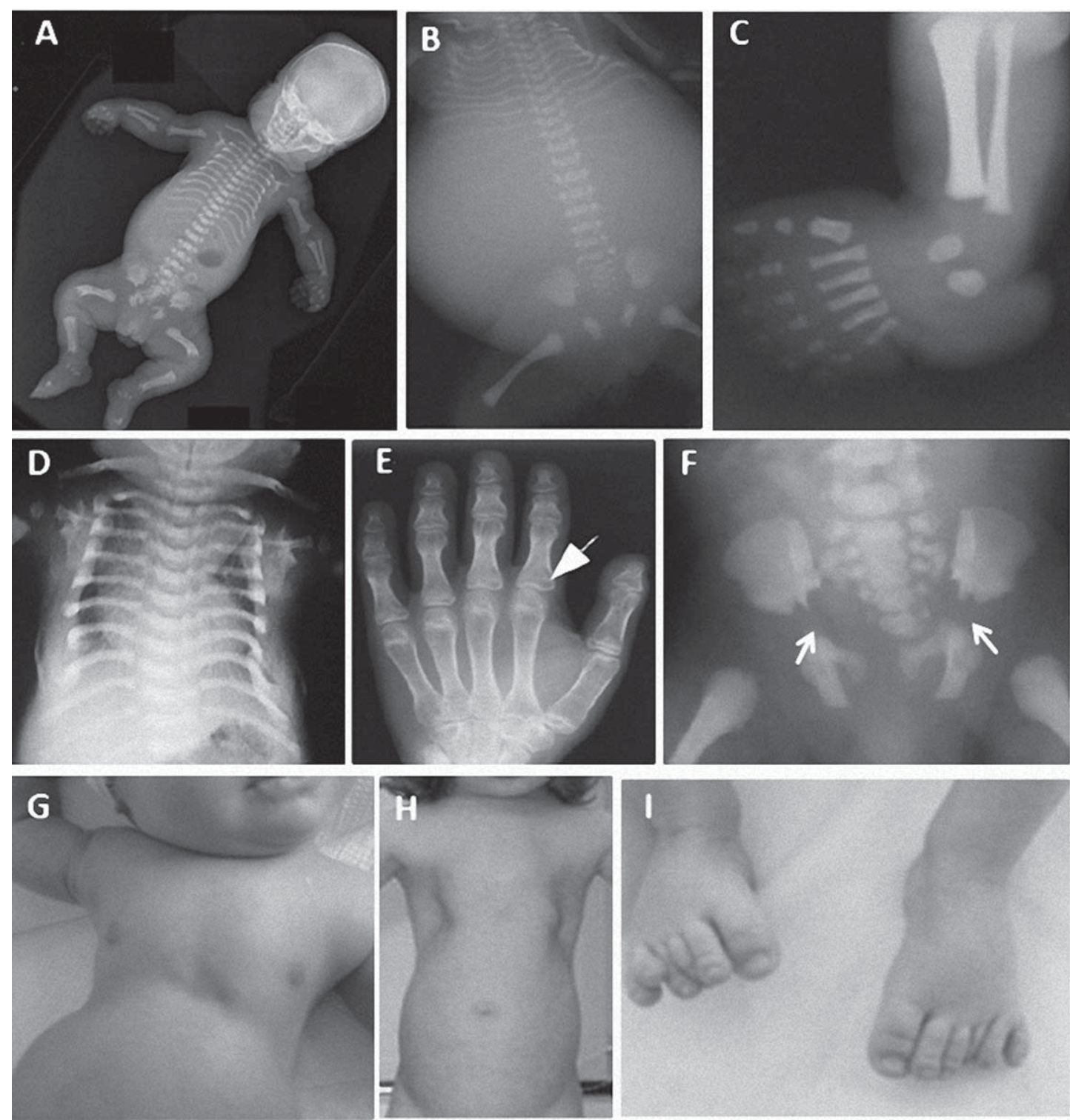

Fig. 2. Phenotypic features of short-rib thoracic dystrophy, oral-facial-digital syndrome 4 and Jeune asphyxiating thoracic dystrophy. Radiological hallmarks of short-rib polydactyly syndrome (A) and oral-facial-digital syndrome 4 (B, C) including shortened long bones and short horizontal ribs, small thorax, protruding abdomen and polydactyly. (D-I) Clinical features of Jeune asphyxiating thoracic dystrophy: narrow thorax (D, G, H), horizontal short ribs and handlebar clavicles (D), acetabular spurs (F) and cone-shaped epiphyses of the phalanges (E). Polydactyly is rarely observed (I). Reprinted with permission from El Hokayem et al. NEK1 and DYNC2H1 are both involved in short-rib polydactyly syndrome. J Med Genet 2012;49(4):227-33. Copyright 2012 J Med Genet. (Picture A); Thomas et al. TCTN3 mutations cause Mohr-Majewski syndrome. Am J Hum Genet 2012;91(2):372-8. Copyright 2012 Am J Hum Genet (pictures B and C); Halbritter et al. Defects in the IFT-B component IFT172 cause Jeune and Mainzer Saldino syndromes in humans. Am J Hum Genet. 2013; 93(5):915-25. Copyright 2013 Am J Hum Genet. (pictures D, G and I); Schmidts et al. Combined NGS approaches identify mutations in the intraflagellar transport gene IFT140 in skeletal ciliopathies with early progressive kidney disease. Hum Mut 2013; 34(5):7714-24. Copyright 2013 Hum Mut (picture E).

spurs. The structure of the pelvis in SRPS-III resembles the pelvis configuration observed in SRPS-I, EVC and JATD. Although commonly observed, polydactyly is not completely penetrant. Cleft lip and palate are reported as well as malformation of the larynx and epiglottis [25, 26]. In contrast to SRPS-I, where developmental urogenital defects seem common, those are rarely observed in SRPS-III [27]. 


\subsubsection{SRPS-II, SRPS-IV and OFD4}

The clinical picture in SRPS-II and SRPS-IV is quite similar with hydropic appearance at birth, short long bones, small and narrow thorax with horizontal ribs and protuberant abdomen [18], but in contrast to SRPS-II, polydactyly is often absent in SRPS-IV. Also, disproportional short tibia (the tibia is shorter than the fibula), a hallmark of SRPS-II, is not observed in SRPS-IV [23]. However, dysplastic tibia also occur in OFD4 (Mohr-Majewski syndrome, Baraitser-Burn syndrome; MIM 258860), presenting with variable thoracic constriction, pre- and postaxial polydactyly of hands and feet, cleft and pseudo-cleft of the lip and/or palate, lobulated tongue, cystic dysplastic kidney and liver involvement, brain malformations [28], severe bilateral deafness [29] and coloboma of the eye [30]. Orofacial clefts, cerebral malformations and renal involvement are also observed in SRPS-II [23, 31], and SRPS-IV [3, 20, 32, 33].

\subsubsection{SRPS-V}

SRPS-V was only recently described and the underlying genetic defect identified in two consecutively affected pregnancies of a mother from Maori descent from New Zealand. Hydrops, narrow chest and severely shortened and bowed long bones displaying lack of ossification, hypoplastic scapulae, and peritoneal calcifications, postaxial poly-syndactyly and cleft palate were reported. Extraskeletal findings include bilateral cystic hygroma, hypospadias, mainly glomerular kidney cysts and intestinal malrotation. Acromesomelic hypomineralization and campomelia distinguish SRPS-V from SRPS subtypes I-III [21, 34].

\subsection{Phenotypic spectrum of childhood chondrodysplasias}

There are a number of ciliary chondrodysplasias that have significant overlap with the SRPS, but that are less severe and occur in childhood and therefore have been summarized with SRPS under the term SRTD. These include JATD, MZSDS, CED, and EVC. WAD in contrast does not affect the thorax.

\subsubsection{JATD}

JATD is characterized by a narrow, sometimes bellshaped thorax due to shortening of the ribs, which restricts pulmonary development and may cause severe respiratory distress during the first two years of life, but compared to SRPS, the phenotype is less severe (Fig. 2). Respiratory problems account for most of the mortality in JATD ranging from $20-60 \%[1,7,35]$, but patients seem to somewhat "grow out" of the respiratory phenotype $[7,35,36]$. Other skeletal hallmarks include pelvis abnormalities similar to those observed in SRPS-I, III and EVC, cone-shaped epiphyses and infrequently polydactyly (Fig. 2). End-stage renal disease in childhood due to NPHP-like (and rarely cystic) kidney involvement affects probably less than $20 \%$ of all individuals with JATD, and seems to depend mainly on the underlying genetic defect with mutations in IFT140 and IFT172 predicting this phenotype with nearly $100 \%$ probability $[8,13,14]$. Patients with mutations in one of those two genes also develop retinal degeneration, while this phenotype has been described as "rare" in literature $[37,38]$. However, Baujat et al. [35] observed electroretinogram (ERG) abnormalities in up to $50 \%$ of JATD patients with $\mathrm{DYNC} 2 \mathrm{H} 1$ mutations but it is not clear to date how many of these patients will develop clinically relevant retinal disease later on. Pancreatic lesions [39], elevated liver enzymes [13, 40] and brain malformations [13, 41, 42] can also occur in JATD. The latter are rare in JATD, but common in Joubert syndrome and can be imaged as a so-called molar tooth sign on magnetic resonance imaging.

\subsection{2. $M Z S D S$}

Like JATD, MZSDS is described as "cono-renal syndrome" due to cone-shaped epiphyses observed radiologically after the first year of life (Fig. 3). This phenotype occurs in association with impaired renal function (due to both polycystic disease and NPHP) and retinal degeneration. Similar as in JATD, the thorax of MZSDS patients is often narrow but to a milder degree [23, 43-45] (Fig. 3). JATD and MZSDS diseases are considered allelic disorders [8, 13, 14]. Like in JATD, age of onset and speed of progression for renal and retinal disease vary between and even within families and complicates accurate prognosis for these patients. Additionally, the information that is currently available about retinal disease relies on different tests (ERG, fundoscopy) that are not equally sensitive, e.g. fundoscopy may appear normal in case of retinal degeneration without pigmentary deposits and although ERG is very informative, it is difficult to obtain reliable ERG results in non-cooperative young children. In summary, accurate conclusions cannot be drawn at the moment but childhood onset for renal 

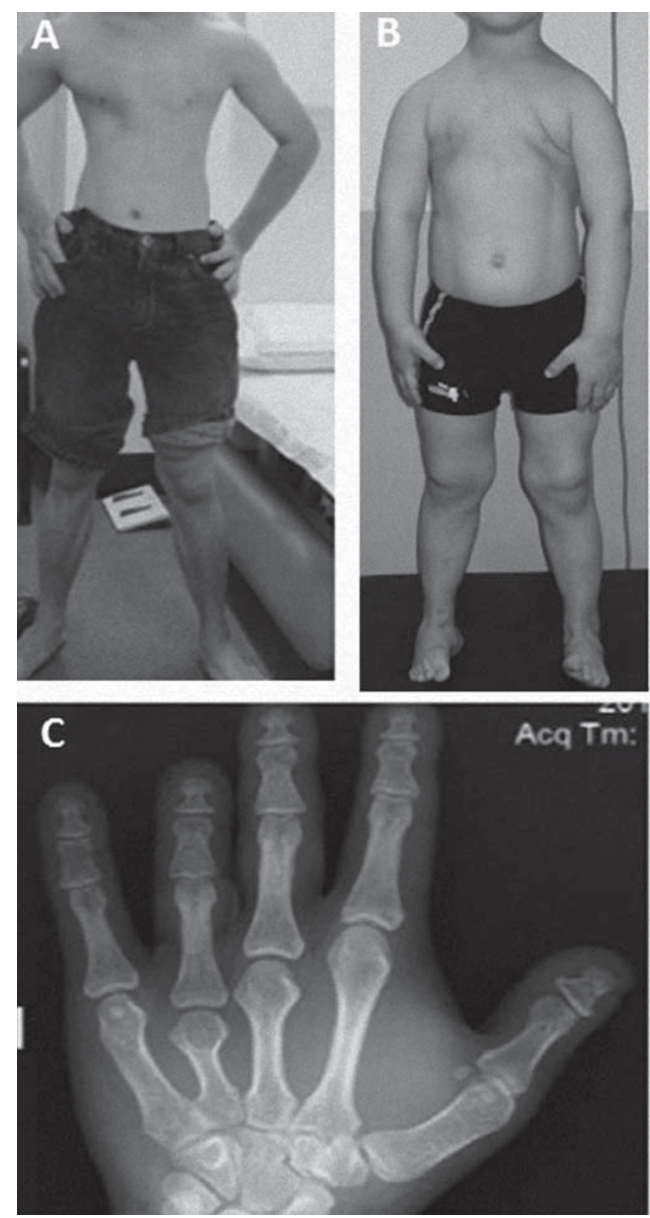
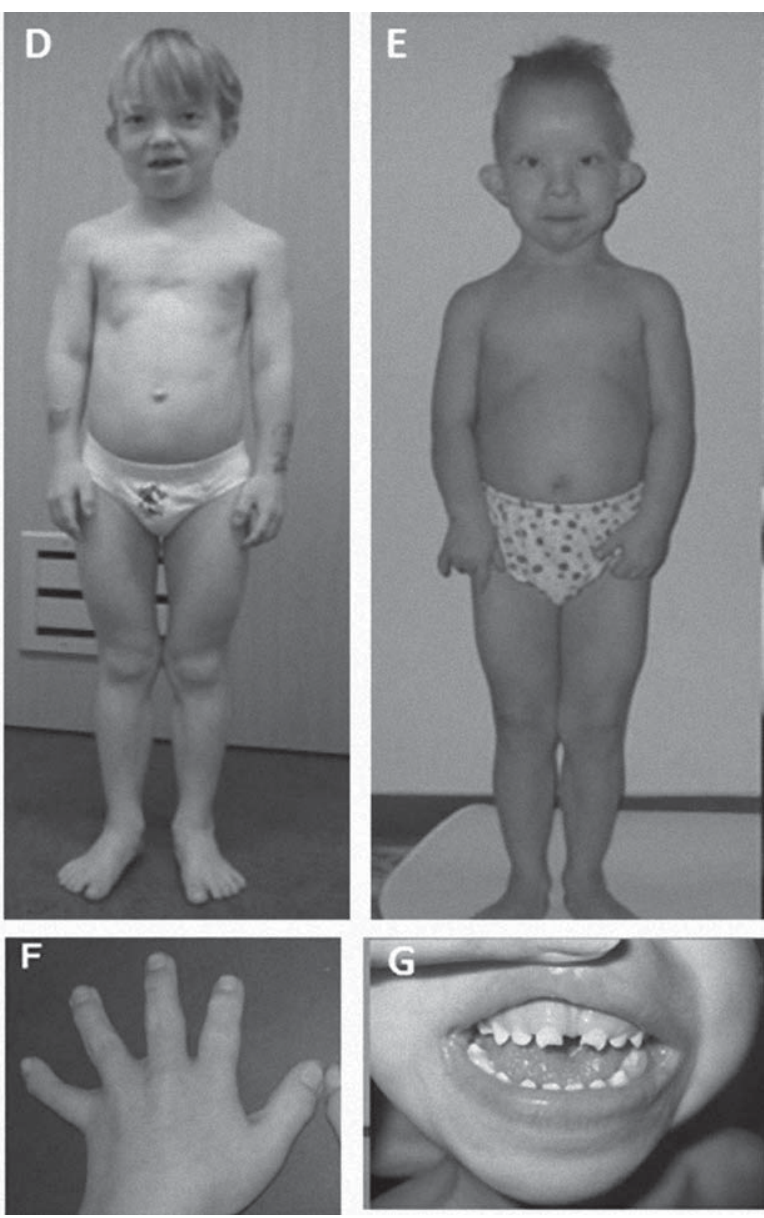

Fig. 3. Clinical hallmarks of Mainzer-Saldino syndrome and Sensenbrenner syndrome. Mildly narrowed thorax (A, B) and brachydactyly with cone-shaped epiphyses of the phalanges (C) define the skeletal phenotype in Mainzer-Saldino syndrome. Reprinted with permission from Perrault et al. Mainzer-Saldino Syndrome is a ciliopathy caused by IFT140 mutations. Am J Hum Genet 2012;90(5):864-70. Copyrgight 2012 Am J Hum Genet. (picture A); Schmidts et al. Combined NGS approaches identify mutations in the intraflagellar transport gene IFT140 in skeletal ciliopathies with early progressive kidney disease. Hum Mut 2013; 34(5):7714-24. Copyright 2013 Hum Mut (picture c); reprinted with permission from Walczak-Sztulpa et al. Cranioectodermal dysplasia, Sensenbrenner syndrome, is a ciliopathy caused by mutations in the IFT122 gene. Am J Hum Genet 2010; 86(6):949-56. Copyright 2010 Am J Hum Mut and from Bedrup et al. Ciliopathies with skeletal anomalies and renal insufficiency due to mutations in the IFT-A gene WDR19. J Med Genet 2011; 89(5); 634-43. Copyright 2011 J Med Genet.

and retinal disease seems common for patients with IFT140 and IFT172 mutations [8, 13, 14]. Hepatic involvement with cholestasis and fibrosis has also been observed in some cases [8,13]. Last, Mainzer et al. [43] and Giedion [46] described some of their of MZSDS patients with ataxia, a finding not confirmed in later studies $[8,13]$.

\subsubsection{Sensenbrenner syndrome}

In contrast to JATD and MZSDS subjects, patients with CED present characteristic facial dysmorphic features and ectodermal defects including nail, hair and teeth abnormalities (Fig. 3). Common skeletal features are rhizomelic micromelia and brachydactyly as well as variable narrowing of the thorax, which is usually milder than what is observed in JATD or SRPS (Fig. 3) [9, 15]. However, dolichocephalus resulting from craniosynostosis of the sutura sagittalis [47], can be helpful to distinguish CED from other ciliopathies [48]. In contrast to JATD and MZSDS, developmental delay and skin laxity, potentially increasing the risk of hernias, can be additional features. Visceral manifestations frequently occur and often include progressive renal failure due to a NPHP-like renal phenotype with small hyperechogenic kidneys, the histological picture of tubulointerstitial nephritis and microscopic 


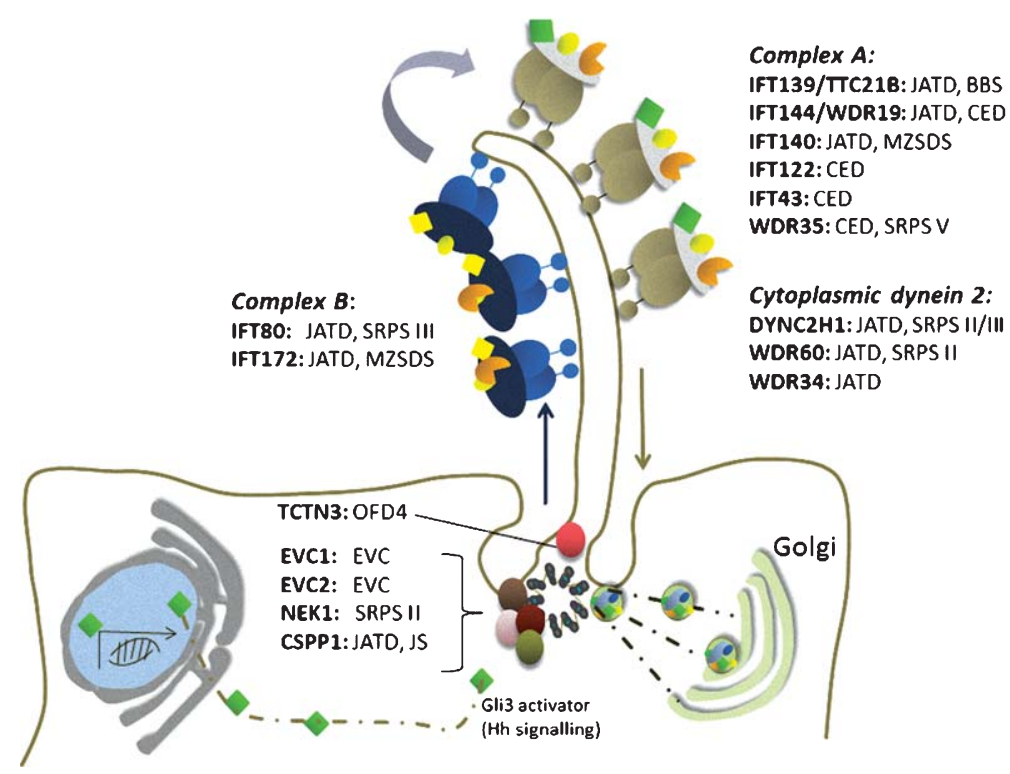

Fig. 4. Schematic presentation of intraflagellar transport. Ciliary proteins are thought to be transported to the cilium within vesicles that merge with the ciliary membrane in the ciliary pocket area. Anterograde intraflagellar transport (IFT) from the ciliary base to the tip is facilitated by IFT complex B, while retrograde transport back the base requires IFT complex A. Most genes found to be involved in ciliary chondrodysplasias encode for proteins of complex A and the associated motor complex, cytoplasmic dynein-2. However, EVC/EVC2, CSPP1 and NEK1 localize to the base of the cilium and TCTN3 is found at the ciliary transition zone. To date, no human mutations have been identified in the motor for complex B, kinesin-2. Hedgehog $(\mathrm{Hh})$ signaling is essential to maintain a balance between proliferation and cellular differentiation at the growth plates. In Hh signaling, activated GLI proteins finally translocate to the nucleus where they influence gene expression. IFT mutant mice as well as mice lacking Evc function show abnormal hedgehog signaling, potentially due to disturbed localization of the hedgehog receptor smoothened to the cilium.

glomerular and tubular cysts $[49,50]$. Hepatic cysts, fibrosis and ductal plate malformation are also common [51-53], while heart defects and retinal dystrophy are less frequent [15].

\subsubsection{EVC syndrome}

EVC was first recognized in 1940 by Ellis and van Creveld [54], and McKusick et al. [55] described a large consanguineous Amish pedigree in Pennsylvania in 1964. Acromelic dwarfism, polydactyly of the hands (but not feet), ectodermal defects such as dysplastic nails and teeth abnormalities (prenatal eruption of teeth, hypodontia and malformed teeth) and cardiac defects are classical hallmarks; EVC is therefore referred to as "six finger dwarfism". The heart defects mainly represent primary atrial septal defects [11, 55] affecting approximately half of all patients. Hydrocephalus due to a Dandy-Walker malformation has also been described [56]. Radi- ological features in EVC, including brachydactyly, polydactyly, short ribs and trident acetabulum with spurs, can make this condition difficult to distinguish from JATD, however, cardiac and ectodermal defects are common in EVC and not a feature of JATD, while JATD patients may rather present with additional renal, liver, and retinal disease not usually observed in EVC [2].

\subsubsection{Weyers acrodental dysostosis (WAD)}

WAD or Curry-Hall syndrome was first described by Weyers [57], and is allelic to EVC, however inherited in an autosomal dominant pattern. Patients present with a milder phenotype consisting of polydactyly of the hands, dentition anomalies such as abnormal shape and number of teeth, and dystrophic nails as well as short stature with short extremities. In contrast to EVC, thoracic constriction and/or visceral involvement is usually not observed [57-60]. 


\section{Progress in gene identification}

Except WAD, ciliary chondrodysplasias are inherited autosomal recessively. Genetic heterogeneity is significant, especially for JATD and CED and genetic overlap is observed between different SRPS types as well as between SRPS, JATD, MZSDS and CED (Fig. 4). Similar to other (genetically heterogeneous) ciliopathies, ciliary chondrodysplasias have hugely benefited from the introduction of next-generation sequencing (NGS) which is currently revolutionising patient genotyping and gene discovery in the research setting in form of gene panel sequencing and whole exome and genome sequencing. This has led to the identification of many new human disease associated genes over the last years, mostly encoding intraflagellar transport (IFT) proteins (IFT172 [13], WDR19 [61], TTC21B [62], IFT140 [8, 14], IFT122 [52], IFT80 [63, 64], IFT43 [65], and WDR35 [21, 66]) or components of the retrograde IFT motor complex dynein-2 (i.e. DYNC2H1 [67-69], WDR34 [70-73], and WDR60 [74, 75]). Further, proteins localizing to the base of the cilium (basal body, peri-basal body region or pericentriolar matrix) seem to play a role as indicated by mutations in genes encoding for NEK1 [69, 76], CSPP1 [42] and EVC/EVC2 [77, 78]. TCTN3, mutated in OFD4, localizes to the ciliary transition zone that forms a barrier between the ciliary and cytoplasmic compartments [79]. The proportion of cases caused by mutations in currently known disease causing genes varies between the different conditions: while the vast majority of EVC cases occurs due to mutations in EVC and EVC2 [80] and causative mutations in $\mathrm{NEK} 1$ and $\mathrm{DYNC} 2 \mathrm{H} 1$ are found in over 2/3 of all SRPS-II cases [69], the majority of all MZSDS are caused by IFT140 and IFT172 mutations [8, 13], and every other OFD4 case appears to result from mutations in TCTN3 [79]. JATD is genetically more heterogeneous. Most cases are caused by mutations in $\mathrm{DYNC} 2 \mathrm{Hl}$ (approximately 50\%) [7, 35], followed by mutations in WDR34 (approximately $10 \%$ ) $[70,71]$, and currently more than $70 \%$ of all patients harboring mutations in known genes. Similarly, multiple genes have been found to cause CED and the frequency of WDR19, IFT122 and WDR35 mutations seems fairly equally distributed, whereas mutations in IFT43 are less commonly identified. The total number of cases reported to date is, however, too small to draw final conclusions in this respect [15].
First genotype-phenotype correlations especially in JATD and MZSDS and the phenotypic spectrum of CED further suggest that mutations in IFT complex A components lead to a rather mild rib phenotype but often cause significant extraskeletal symptoms such as renal, hepatic and retinal disease [8,13-15], while DYNC2H1 mutations are associated with a very severe thorax phenotype but infrequent clinically relevant renal or eye involvement in affected children [7, 35].

Digenic inheritance of heterozygous mutations in two different genes has been reported in a single case of SRPS-II with a heterozygous mutation in NEK1 as well as $\mathrm{DYNC} 2 \mathrm{HI}$ [76]. So-called "triallelic inheritance", previously described in other ciliopathies such as Bardet-Biedl syndrome [81] has not been described in ciliary dysplasias to date. However, there are indications that "mutational load" (the total of mutations in genes known to cause the disease), could potentially play a role in ciliary chondrodysplasias [14].

\section{Molecular mechanisms}

Many genes implicated in ciliary chondrodysplasias to date encode for proteins involved in IFT, mostly components of the IFT complex A (retrograde transport) $[8,14,21,52,61,62,65,66]$, but also two components of IFT complex B (anterograde transport) $[13,63]$ as well as the dynein-2 complex representing the motor for IFT-A [67, 68, 70, 71, 74]. EVC and EVC2 are found at the ciliary base [82], but do not seem to be involved in IFT, while NEKI encodes a serine/threonine kinase involved in the control of cell-cycle dependent ciliogenesis [76]. CSPP1 also localizes to the base of the cilium but its function there has not been elucidated to date [42, 83, 84]. Last, TCTN3 is found in a complex with TCTN1 and TCTN2 at the ciliary transition zone [79] (Fig. 4).

Because the cilium does not have a protein synthesis machinery, all required proteins are produced within the cell body and transported to the base of the cilium where they are subsequently loaded onto IFT particles, which facilitate transport along the ciliary axoneme towards the ciliary tip (anterograde IFT, complex $\mathrm{B}$, powered by kinesin motor complexes). IFT is also required to translocate molecules back towards the base of the cilium (retrograde IFT, complex A, powered by the dynein-2 complex) [85-87]. Dysfunctional IFT therefore leads to transport defects along the ciliary axoneme, causing ciliogenesis defects with absent or very short cilia in extreme cases [4]. Mild forms of 
such defects have been described for patient's fibroblasts with mutations in DYNC2H1, NEK1, WDR19 and WDR60 [61, 68, 74, 76]. However, in other patients with mutations in genes encoding for retrograde IFT proteins or the retrograde motor protein DYNC2H1, cilia seem to be present on skin fibroblasts in normal numbers and reach normal length, but accumulation of IFT-B components at the ciliary tip can be observed [7, 65]. While the Dync $2 h l$ knockout mice display a severe ciliogenesis defect [88], the milder cellular human phenotype presumably results from hypomorphic missense mutations found in human patients [7]. Further, as expected, mutations in IFT172, impairing anterograde transport, result in reduced incorporation of ciliary proteins such as adenylate cyclase III and IFT molecules into the ciliary axoneme [13].

As the cilium transmits signals from outside the cell to the inside (serving as an "antenna") and also processes signals from within the cell [89-92], lack of primary cilia or impaired IFT resulting in accumulation or lack of signal transduction particles critically interrupts the flow of cellular signaling information causing severe developmental defects [93, 94]. Cartilage and bone development and growth is influenced by many fundamental cell signaling pathways, but the hedgehog signaling pathway has been identified as crucially influencing chondrogenic (and subsequently osteogenic) proliferation and differentiation [95]. Mouse models for Evc, Dync $2 \mathrm{hl}$ and Ift80 indicate that IFT defects indeed lead to imbalances in the hedgehog signaling pathway causing a premature stop of chondrogenic proliferation and induction of chondrogenic differentiation at the growth plates severely slowing down bone growth [82, 96]. IFT-A mouse mutants seem to display ligand independent expansion of hedgehog signaling resulting in abnormal digit numbers and oro-facial clefts [88] (Fig. 4).

Renal and retinal disease are frequent ciliopathy symptoms in ciliary chondrodysplasias [6] and seem to mainly result from mutations in IFT-A genes $[8,14$, 15] and the IFT-B component encoded by IFT172 [13], while these traits are less frequently observed in surviving patients with $D Y N C 2 H 1$ [7, 35] or IFT8O [63] mutations. The underlying pathophysiological mechanism remains to be defined. Cells in the kidney tubules exhibit primary cilia, and loss of the physical structure of the cilium as well as loss of ciliary proteins has been shown to lead to renal cyst formation in mice [97-99]. While hypomorphic Ift 80 knockout mice do not exhibit any renal phenotype [96], loss of Ift140, or Ift172 in mice produces an early onset kidney phenotype [100, 101], resembling human phenotype. Ift140 knockout mice show normally orientated mitotic spindle axis, but hyper-proliferation of renal tubular cells was noted in the pre-cystic epithelium, while increased canonical Wnt and hedgehog signaling was only observed in cystic tissue [100]. Unbalances between the canonical and non-canonical Wnt pathways with loss of non-canonical and increased canonical signaling have been previously associated with dysfunction of genes causing NPHP when disrupted. The best known example concerns the INVS gene encoding inversin: loss of function causes situs inversus and NPHP in humans and mice, and inversin was shown to facilitate a switch from canonical to noncanonical Wnt signaling in vivo as well as in vitro, probably by targeting cytoplasmic disheveled for ubiquitin-dependent degradation and thereby reducing canonical Wnt signaling and promoting non-canonical Wnt or planar cell polarity (PCP) signaling [102, 103]. Neither disturbances in hedgehog nor Wnt signaling seem to initiate cyst formation in Ift140 knockout mice but might contribute to cyst progression. How this relates to the human pathophysiology remains to be defined.

Retinal photoreceptors consist of two parts crucial for light processing: the inner and outer segment. These segments are connected via a narrow bridge, the so-called "connecting cilium" which shares similarities with the transition zone of a classical cilium. The connecting cilium is essential for (IFT-molecule dependent) rhodopsin transport between the segments and impaired transport results in accumulation of rhodopsin causing photoreceptor death [72,104-106]. In contrast to the primarily developmental skeletal phenotype resulting from IFT mutations, the retinal phenotype therefore appears to be a degenerative process. Like the renal phenotype, retinal degeneration seems to be associated with mutations in IFT-A genes and IFT172 [8,13-15], while it appears less common in subjects with $\mathrm{DYNC} 2 \mathrm{H} 1$ mutations [7, 35].

\section{Clinical management and future perspectives}

Ciliary chondrodysplasias are rare diseases and no large long-term follow-up studies have been performed to date. Curative therapies are not currently available and treatment is therefore symptomatic. For SRPS subtypes I-V, only short-term palliative care is possible and therefore interruption of the pregnancy is usually 
recommended. OFD4, JATD, MZSDS, CED and EVC patients in contrast require complex multidisciplinary long-term clinical management approaches $[2,35,36]$.

\subsection{Skeleton}

Lethality in ciliary chondrodysplasias is mainly thought to be a result of cardiorespiratory failure due to lung hypoplasia secondary to the constricted ribcage (this does not occur in WAD). The majority of fatalities occur in JATD and are observed perinatally and up to the second birthday. Mechanical ventilation, continuous positive airway pressure ventilation or oxygen supply can be necessary for a long time. However, as many patients seem to "grow out" of the thoracic phenotype, invasive therapy is rarely required later in life $[2,6,7,35,36]$. Thoracic expansion surgery may be offered in cases where conservative treatment is insufficient in a handful of highly specialized centers worldwide, however, this treatment imposes a significant risk [36, 107-111]. Pulmonary function should be assessed by spirometry and volume measurements as well as polygraphic sleep studies; these assays should be performed every one to two years [35].

If ciliary chondrodysplasias cause secondary and/or degenerative skeletal health issues later in life is not clear to date due to lack of larger long-term follow-up studies, but scoliosis appears to be a frequent feature in JATD $[7,35]$. While for subjects with EVC body length ranges from $119 \mathrm{~cm}$ to $167 \mathrm{~cm}$ have been reported [2, 112, 113], many JATD patients reach normal adult height [7, 35] with the exception of patients with impaired renal function [14]. Growth hormone treatment is currently not recommended for patients with ciliary chondrodysplasias [2]. Extra fingers, neonatal teeth and craniosynostosis might require surgical correction in the first $1-2 \mathrm{yr}$ of life and additional orthodontic corrections may be required later on.

\subsection{Extraskeletal disease}

Yearly monitoring of renal- and hepatic blood markers as well as ultrasound examination should be performed, especially for patients with MZSDS and CED as well as JATD individuals with WDR19, IFT140 or IFT172 mutations [8, 13-15]. JATD patients with IFT8O and DYNC2H1 mutations seem at a lower risk $[7,35,63]$. Supportive therapy includes dialysis and/or renal/liver transplantation. The limited available data suggests that most JATD and CED patients exhibit mild liver disease [35, 36] with only a handful of cases progressing into liver failure reported [13, 40, 114]. Elevated liver enzymes in JATD seem to respond to ursodeoxycholic acid treatment [35, 115]. Liver disease is not associated with EVC and is infrequent in MZSDS [2, 8, 13].

Patients with CED, MZSDS as well as JATD patients with WDR19, IFT140 or IFT172 mutations are at significant risk of developing retinal degeneration, mainly with childhood onset [8, 13, 14]. As ERG changes precede pathological findings in fundoscopy and clinical manifestation of retinal dystrophy, eye monitoring should always include ERG [116]. That said, it may be difficult to obtain reliable ERG results in young children. Clinically relevant sight loss seems to occur less in young individuals with $\mathrm{DYNC} 2 \mathrm{H} 1$ mutations [7]. Nevertheless, these patients also require monitoring as ERG abnormalities were noted in up to $50 \%$ of cases [35]. Clinically relevant heart defects should be treated according to cardiological guidelines, however, heart defects can shorten life expectancy depending on the defect and depending on if surgery is needed and what kind of operation is required [2, 117]. Postoperative mortality was reported as high as $44 \%$ in a small Amish cohort with EVC [16].

Although most CED, JATD and MZSDS patients develop normally, clinical and radiological features of Joubert syndrome have been observed in a few JATD and CED patients [41, 42] and some MZSDS patients with ataxia $[43,46]$. Evaluation by pediatric neurology specialist should be undertaken for cases with neurological symptoms and/or developmental delay.

Therapy in ciliary chondrodysplasias is currently symptomatic and supportive only. It will be challenging to attempt to therapeutically influence the skeletal phenotype; first because one would have to start treatment at birth or even in utero, and second because the developing skeleton is not as easily accessible, e.g. the respiratory tract, in case one would want to develop gene therapy. The size of some of the genes involved (e.g. DYNC2HI and IFT172) represents an additional hurdle. As most mutations are missense changes, readthrough drugs such as PTC124/ataluren will not be applicable to many patients.

\subsection{Psychological and genetic counseling}

As ciliary chondrodysplasias have significant psychological impact on affected families due to (often late) interruptions of pregnancies, loss of children in 
the neonatal period or infancy, and chronic disease with potential life threatening complications, psychological counseling should be offered.

Genetic counseling is recommended for all ciliary chondrodysplasias as the recurrence risk is $25 \%$ for subsequent pregnancies, except for WAD with a risk of $50 \%$. Prenatal genetic testing should be offered to families where the causative mutation is known and families should be informed about the possibility of pre-implantation diagnostics as well as sperm or egg cell donation. That said, significant variability of the phenotype severity is observed between patients from different families with mutations in the same gene as well as between siblings carrying the same mutations $[7,74]$ can make it difficult to predict the exact phenotype for subsequent pregnancies based on genetic findings.

In the past, extensive genetic- and phenotypical heterogeneity as well as overlap between the different disease entities have made it difficult to establish a molecular diagnosis. However, the introduction of NGS has significantly facilitated genetic diagnostics, either in form of specific gene panels or whole-exome sequencing. Single gene analysis still has a fairly high success rate in EVC (EVC, EVC2), SRPS-II (NEK1), OFD4 (TCTN3), and SRPS-V (WDR35), while in other cases and for subjects where targeted sequencing of the major causative gene does not reveal any mutations, gene panel analysis seems more appropriate. For instance, although the majority of all JATD cases seem to be caused by mutations in $\mathrm{DYNC} 2 \mathrm{Hl}$, due to the large size of this gene, Sanger sequencing is both relatively expensive and inefficient. Generally, if no causative mutation can be identified using targeted NGS panel approach, whole-exome and/or wholegenome analysis might reveal the underlying genetic defect. Copy number variant analysis of NGS data, especially in exome- and whole-genome data, is highly recommended [7].

In summary, ciliary chondrodysplasias require multidisciplinary long-term clinical management coordinated by the discipline most closely involved with the patient. This can be best achieved in a centre with experience with ciliary chondrodysplasias and all disciplines located within this centre.

\section{Acknowledgments}

Sincere apologies to all colleagues whose findings could not be cited due to limited space. I am grateful for funding from the Dutch Kidney Foundation, DKF (KOUNCIL, CP11.18) and Action Medical Research UK (RTF-1411, clinical training fellowship).

\section{References}

[1] Oberklaid F, Danks DM, Mayne V, Campbell P. Asphyxiating thoracic dysplasia. Clinical, radiological, and pathological information on 10 patients. Arch Dis Child 1977;52(10):758-65.

[2] Baujat G, Le Merrer M. Ellis-van Creveld syndrome. Orphanet J Rare Dis 2007;2:27.

[3] Kovács N, Sárkány I, Mohay G, Adamovich K, Ertl T, Kosztolányi $\mathrm{G}$, et al. High incidence of short rib-polydactyly syndrome type IV in a Hungarian Roma subpopulation. Am J Med Genet A 2006;140(24):2816-8.

[4] Fliegauf M, Benzing T, Omran H. When cilia go bad: Cilia defects and ciliopathies. Nat Rev Mol Cell Biol 2007;8(11):880-93.

[5] Baker K, Beales PL. Making sense of cilia in disease: The human ciliopathies. Am J Med Genet C Semin Med Genet 2009;151C(4):281-95.

[6] Huber C, Cormier-Daire V. Ciliary disorder of the skeleton. Am J Med Genet C Semin Med Genet 2012;160C(3):16574.

[7] Schmidts M, Arts HH, Bongers EM, Yap Z, Oud MM, Antony D, et al. Exome sequencing identifies DYNC2H1 mutations as a common cause of asphyxiating thoracic dystrophy (Jeune syndrome) without major polydactyly, renal or retinal involvement. J Med Genet 2013;50(5): 309-23.

[8] Perrault I, Saunier S, Hanein S, Filhol E, Bizet AA, Collins $\mathrm{F}$, et al. Mainzer-Saldino syndrome is a ciliopathy caused by IFT140 mutations. Am J Hum Genet 2012;90(5):864-70.

[9] Levin LS, Perrin JC, Ose L, Dorst JP, Miller JD, McKusick VA. A heritable syndrome of craniosynostosis, short thin hair, dental abnormalities, and short limbs: Cranioectodermal dysplasia. J Pediatr 1977;90(1):55-61.

[10] Hills CB, Kochilas L, Schimmenti LA, Moller JH. Ellis-van Creveld syndrome and congenital heart defects: Presentation of an additional 32 cases. Pediatr Cardiol 2011;32(7): 97782.

[11] Blackburn MG, Belliveau RE. Ellis-van Creveld syndrome A report of previously undescribed anomalies in two siblings. Am J Dis Child 1971;122(3):267-70.

[12] Elcioglu NH, Hall CM. Diagnostic dilemmas in the short rib-polydactyly syndrome group. Am J Med Genet 2002;111(4):392-400.

[13] Halbritter J, Bizet AA, Schmidts M, Porath JD, Braun DA, Gee HY, et al. Defects in the IFT-B component IFT172 cause Jeune and Mainzer-Saldino syndromes in humans. Am J Hum Genet 2013;93(5):915-25.

[14] Schmidts M, Frank V, Eisenberger T, Al Turki S, Bizet AA, Antony D, et al. Combined NGS approaches identify mutations in the intraflagellar transport gene IFT140 in skeletal ciliopathies with early progressive kidney disease. Hum Mutat 2013;34(5):714-24.

[15] Lin AE, Traum AZ, Sahai I, Keppler-Noreuil K, Kukolich MK, Adam MP, et al. Sensenbrenner syndrome (Cranioectodermal dysplasia): Clinical and molecular analyses of 39 
patients including two new patients. Am J Med Genet A 2013;161A(11):2762-76.

[16] O'Connor MJ, Collins RT, 2nd. Ellis-van Creveld syndrome and congenital heart defects: Presentation of an additional 32 cases. Pediatr Cardiol 2012;33(4):491; discussion 491-2.

[17] Saldino RM, Noonan CD. Severe thoracic dystrophy with striking micromelia, abnormal osseous development, including the spine, and multiple visceral anomalies. Am J Roentgenol Radium Ther Nucl Med 1972;114(2): 257-63.

[18] Majewski F, Pfeiffer RA, Lenz W, Muller R, Feil G, Seiler R. Polysyndactyly, short limbs, and genital malformationsa new syndrome? Z Kinderheilkd 1971;111(2):118-38 (in German).

[19] Verma IC, Bhargava S, Agarwal S. An autosomal recessive form of lethal chondrodystrophy with severe thoracic narrowing, rhizoacromelic type of micromelia, polydacytly and genital anomalies. Birth Defects Orig Artic Ser 1975;11(6):167-74

[20] Beemer FA, Langer LO Jr, Klep-de Pater JM, Hemmes AM, Bylsma JB, Pauli RM, et al. A new short rib syndrome: Report of two cases. Am J Med Genet 1983;14(1): 115-23.

[21] Mill P, Lockhart PJ, Fitzpatrick E, Mountford HS, Hall EA, Reijns MA, et al. Human and mouse mutations in WDR35 cause short-rib polydactyly syndromes due to abnormal ciliogenesis. Am J Hum Genet 2011;88(4):508-15.

[22] Spranger J, Grimm B, Weller M, Weissenbacher G, Herrmann J, Gilbert E, et al. Short rib-polydactyly (SRP) syndromes, types Majewski and Saldino-Noonan. Z Kinderheilkunde 1974;116(2):73-94 (in German).

[23] Spranger J, Langer LO, Weller MH, Herrmann J. Short ribpolydactyly syndromes and related conditions. Birth Defects Orig Artic Ser 1974;10(9):117-23.

[24] Le Marec B, Passarge E, Dellenbach P, Kerisit J, Signargout J, Ferrand B, et al. Lethal neonatal forms of chondroectodermal dysplasia. Apropos of 5 cases. Ann Radiol (Paris) 1973;16(1):19-26 (in French).

[25] Naumoff P, Young LW, Mazer J, Amortegui AJ. Short rib-polydactyly syndrome type 3. Radiology 1977;122(2): 443-7.

[26] Bernstein R, Isdale J, Pinto M, Du Toit Zaaijman J, Jenkins T. Short rib-polydactyly syndrome: A single or heterogeneous entity? A re-evaluation prompted by four new cases. J Med Genet 1985;22(1):46-53.

[27] Yang SS, Langer LO Jr, Cacciarelli A, Dahms BB, Unger ER, Roskamp J, et al. Three conditions in neonatal asphyxiating thoracic dysplasia (Jeune) and short rib-polydactyly syndrome spectrum: A clinicopathologic study. Am J Med Genet Suppl 1987;3:191-207.

[28] Baraitser M. The orofaciodigital (OFD) syndromes. J Med Genet 1986;23(2):116-9.

[29] Nevin NC, Thomas PS. Orofaciodigital syndrome type IV: Report of a patient. Am J Med Genet 1989;32(2):151-4.

[30] Ades LC, Clapton WK, Morphett A, Morris LL, Haan EA. Polydactyly, campomelia, ambiguous genitalia, cystic dysplastic kidneys, and cerebral malformation in a fetus of consanguineous parents: A new multiple malformation syndrome, or a severe form of oral-facial-digital syndrome type IV? Am J Med Genet 1994;49(2):211-7.

[31] Chen H, Yang SS, Gonzalez E, Fowler M, Al Saadi A. Short rib-polydactyly syndrome, Majewski type. Am J Med Genet 1980;7(2):215-22.
[32] Passarge E. Familial occurrence of a short rib syndrome with hydrops fetalis but without polydactyly. Am J Med Genet 1983;14(2):403-5.

[33] Yang SS, Roth JA, Langer LO Jr. Short rib syndrome Beemer-Langer type with polydactyly: A multiple congenital anomalies syndrome. Am J Med Genet 1991;39(3):243-6.

[34] Kannu P, McFarlane JH, Savarirayan R, Aftimos S. An unclassifiable short rib-polydactyly syndrome with acromesomelic hypomineralization and campomelia in siblings. Am J Med Genet A 2007;143A(21):2607-11.

[35] Baujat G, Huber C, El Hokayem J, Caumes R, Do Ngoc Thanh C, David A, et al. Asphyxiating thoracic dysplasia: Clinical and molecular review of 39 families. J Med Genet 2013;50(2):91-8.

[36] de Vries J, Yntema JL, van Die CE, Crama N, Cornelissen EA, Hamel BC. Jeune syndrome: Description of 13 cases and a proposal for follow-up protocol. Eur J Pediatr 2010;169(1):77-88.

[37] Allen AW Jr, Moon JB, Hovland KR, Minckler DS. Ocular findings in thoracic-pelvic-phalangeal dystrophy. Arch Ophthalmol 1979;97(3):489-92.

[38] Bard LA, Bard PA, Owens GW, Hall BD. Retinal involvement in thoracic-pelvic-phalangeal dystrophy. Arch Ophthalmol 1978;96(2):278-81.

[39] Hopper MS, Boultbee JE, Watson AR. Polyhydramnios associated with congenital pancreatic cysts and asphyxiating thoracic dysplasia. A case report. S Afr Med J 1979;56(1): 32-3.

[40] Yerian LM, Brady L, Hart J. Hepatic manifestations of Jeune syndrome (asphyxiating thoracic dystrophy). Semin Liver Dis $2003 ; 23(2): 195-200$.

[41] Lehman AM, Eydoux P, Doherty D, Glass IA, Chitayat D, Chung BY, et al. Co-occurrence of Joubert syndrome and Jeune asphyxiating thoracic dystrophy. Am J Med Genet A 2010;152A(6):1411-9.

[42] Tuz K, Bachmann-Gagescu R, O’Day DR, Hua K, Isabella $\mathrm{CR}$, Phelps IG, et al. Mutations in CSPP1 cause primary cilia abnormalities and Joubert syndrome with or without Jeune asphyxiating thoracic dystrophy. Am J Hum Genet 2014;94(1):62-72.

[43] Mainzer F, Saldino RM, Ozonoff MB, Minagi H. Familial nephropathy associated with retinitis pigmentosa, cerebellar ataxia and skeletal abnormalities. Am J Med 1970;49(4):556-62

[44] Popovic-Rolovic M, Calic-Perisic N, Bunjevacki G, Negovanovic D. Juvenile nephronophthisis associated with retinal pigmentary dystrophy, cerebellar ataxia, and skeletal abnormalities. Arch Dis Child 1976;51(10):801-3.

[45] Robins DG, French TA, Chakera TM. Juvenile nephronophthisis associated with skeletal abnormalities and hepatic fibrosis. Arch Dis Child 1976;51(10): 799-801.

[46] Giedion A. Phalangeal cone shaped epiphysis of the hands $(\mathrm{PhCSEH})$ and chronic renal disease-the conorenal syndromes. Pediatr Radiol 1979;8(1):32-8.

[47] Amar MJ, Sutphen R, Kousseff BG. Expanded phenotype of cranioectodermal dysplasia (Sensenbrenner syndrome). Am J Med Genet 1997;70(4):349-52

[48] Arts H, Knoers N. Cranioectodermal dysplasia. In: Pagon RA, Adam MP, Ardinger HH, Bird TD, Dolan CR, Fong CT, Smith RJH, Stephens K, editors. GeneReviews ${ }^{\circledR}$ [Internet]. Seattle (WA): University of Washington, 1993-2014. Avail- 
able at: http://www.ncbi.nlm.nih.gov/books/NBK154653/. Accessed September 12, 2013

[49] Lang GD, Young ID. Cranioectodermal dysplasia in sibs. J Med Genet 1991;28(6):424.

[50] Eke T, Woodruff G, Young ID. A new oculorenal syndrome: Retinal dystrophy and tubulointerstitial nephropathy in cranioectodermal dysplasia. Br J Ophthalmol 1996;80(5): 490-1.

[51] Zaffanello M, Diomedi-Camassei F, Melzi ML, Torre G, Callea F, Emma F. Sensenbrenner syndrome: A new member of the hepatorenal fibrocystic family. Am J Med Genet A 2006;140(21):2336-40.

[52] Walczak-Sztulpa J, Eggenschwiler J, Osborn D, Brown DA, Emma F, Klingenberg C, et al. Cranioectodermal dysplasia, Sensenbrenner syndrome, is a ciliopathy caused by mutations in the IFT122 gene. Am J Hum Genet 2010;86(6):949-56

[53] Konstantinidou AE, Fryssira H, Sifakis S, Karadimas C, Kaminopetros P, Agrogiannis G, et al. Cranioectodermal dysplasia: A probable ciliopathy. Am J Med Genet A 2009;149A(10):2206-11.

[54] Ellis RW, van Creveld S. A syndrome characterized by ectodermal dysplasia, polydactyly, chondro-dysplasia and congenital morbus cordis: Report of three cases. Arch Dis Child 1940;15(82):65-84

[55] McKusick VA, Eldridge R, Hostetler JA, Egeland JA. Dwarfism in the Amish. Trans Assoc Am Physicians 1964;77:151-68.

[56] Zangwill KM, Boal DK, Ladda RL. Dandy-Walker malformation in Ellis-van Creveld syndrome. Am J Med Genet 1988;31(1):123-9.

[57] Weyers H. A correlated abnormality of the mandible and extremities (dysostosis acrofacialis). Fortschr Geb Rontgenstr 1952;77(5):5 (in German).

[58] Roubicek M, Spranger J. Weyers acrodental dysostosis in a family. Clin Genet 1984;26(6):587-90.

[59] Roubicek M, Spranger J. Syndrome of polydactyly, conical teeth and nail dysplasia. Am J Med Genet 1985;20(1): 205-7.

[60] Curry CJ, Hall BD. Polydactyly, conical teeth, nail dysplasia, and short limbs: A new autosomal dominant malformation syndrome. Birth Defects Orig Artic Ser 1979;15(5B):253-63

[61] Bredrup C, Saunier S, Oud MM, Fiskerstrand T, Hoischen A, Brackman D, et al. Ciliopathies with skeletal anomalies and renal insufficiency due to mutations in the IFT-A gene WDR19. Am J Med Genet 2011;89(5):634-43.

[62] Davis EE, Zhang Q, Liu Q, Diplas BH, Davey LM, Hartley J, et al. TTC21B contributes both causal and modifying alleles across the ciliopathy spectrum. Nat Genet 2011;43(3):18996.

[63] Beales PL, Bland E, Tobin JL, Bacchelli C, Tuysuz B, Hill $\mathrm{J}$, et al. IFT80, which encodes a conserved intraflagellar transport protein, is mutated in Jeune asphyxiating thoracic dystrophy. Nat Genet 2007;39(6):727-9.

[64] Cavalcanti DP, Huber C, Sang KH, Baujat G, Collins F, Delezoide AL, et al. Mutation in IFT80 in a fetus with the phenotype of Verma-Naumoff provides molecular evidence for Jeune-Verma-Naumoff dysplasia spectrum. J Med Genet 2011;48(2):88-92.

[65] Arts HH, Bongers EM, Mans DA, van Beersum SE, Oud MM, Bolat E, et al. C14ORF179 encoding IFT43 is mutated in Sensenbrenner syndrome. J Med Genet 2011;48(6): 390-5.
[66] Gilissen C, Arts HH, Hoischen A, Spruijt L, Mans DA Arts $\mathrm{P}$, et al. Exome sequencing identifies WDR35 variants involved in Sensenbrenner syndrome. Am J Med Genet 2010;87(3):418-23.

[67] Dagoneau N, Goulet M, Genevieve D, Sznajer Y, Martinovic J, Smithson S, et al. DYNC2H1 mutations cause asphyxiating thoracic dystrophy and short rib-polydactyly syndrome type III. Am J Hum Genet 2009;84(5):706-11.

[68] Merrill AE, Merriman B, Farrington-Rock C, Camacho N, Sebald ET, Funari VA, et al. Ciliary abnormalities due to defects in the retrograde transport protein DYNC2H1 in short-rib polydactyly syndrome. Am J Hum Genet 2009;84(4):542-9.

[69] El Hokayem J, Huber C, Couve A, Aziza J, Baujat G, Bouvier $\mathrm{R}$, et al. NEK1 and DYNC2H1 are both involved in short rib polydactyly Majewski type but not in Beemer Langer cases. J Med Genet 2012;49(4):227-33.

[70] Schmidts M, Vodopiutz J, Christou-Savina S, Cortes CR, McInerney-Leo AM, Emes RD, et al. Mutations in the gene encoding IFT dynein complex component WDR34 cause Jeune asphyxiating thoracic dystrophy. Am J Med Genet 2013;93(5):932-44.

[71] Huber C, Wu S, Kim AS, Sigaudy S, Sarukhanov A, Serre $\mathrm{V}$, et al. WDR34 mutations that cause short-rib polydactyly syndrome type III/severe asphyxiating thoracic dysplasia reveal a role for the NF-kappaB pathway in cilia. Am J Med Genet 2013;93(5):926-31.

[72] Krock BL, Mills-Henry I, Perkins BD. Retrograde intraflag ellar transport by cytoplasmic dynein-2 is required for outer segment extension in vertebrate photoreceptors but not arrestin translocation. Invest Ophthalmol Vis Sci 2009;50(11):5463-71.

[73] Rompolas P, Pedersen LB, Patel-King RS, King SM Chlamydomonas FAP133 is a dynein intermediate chain associated with the retrograde intraflagellar transport motor J Cell Sci 2007;120(Pt 20):3653-65.

[74] McInerney-Leo AM, Schmidts M, Cortes CR, Leo PJ, Gener B, Courtney AD, et al. Short-rib polydactyly and Jeune syndromes are caused by mutations in WDR60. Am J Hum Genet 2013;93(3):515-23

[75] Patel-King RS, Gilberti RM, Hom EF, King SM. WD60/FAP163 is a dynein intermediate chain required for retrograde intraflagellar transport in cilia. Mol Biol Cell 2013;24(17):2668-77.

[76] Thiel C, Kessler K, Giessl A, Dimmler A, Shalev SA von der Haar S, et al. NEK1 mutations cause short-rib polydactyly syndrome type Majewski. Am J Hum Genet 2011;88(1):106-14.

[77] Ruiz-Perez VL, Ide SE, Strom TM, Lorenz B, Wilson D, Woods K, et al. Mutations in a new gene in Ellis-van Creveld syndrome and Weyers acrodental dysostosis. Nat Genet 2000;24(3):283-6

[78] Tompson SW, Ruiz-Perez VL, Blair HJ, Barton S, Navarro V, Robson JL, et al. Sequencing EVC and EVC2 identifies mutations in two-thirds of Ellis-van Creveld syndrome patients. Hum Genet 2007;120(5):663-70.

[79] Thomas S, Legendre M, Saunier S, Bessieres B, Alby C, Bonniere M, et al. TCTN3 mutations cause Mohr-Majewski syndrome. Am J Hum Genet 2012;91(2):372-8.

[80] D'Asdia MC, Torrente I, Consoli F, Ferese R, Magliozzi M, Bernardini L, et al. Novel and recurrent EVC and EVC2 mutations in Ellis-van Creveld syndrome and Weyers acrofacial dyostosis. Eur J Med Genet 2013;56(2):80-7. 
[81] Katsanis N, Ansley SJ, Badano JL, Eichers ER, Lewis RA, Hoskins BE, et al. Triallelic inheritance in BardetBiedl syndrome, a Mendelian recessive disorder. Science 2001;293(5538):2256-9.

[82] Ruiz-Perez VL, Blair HJ, Rodriguez-Andres ME, Blanco MJ, Wilson A, Liu YN, et al. Evc is a positive mediator of Ihh-regulated bone growth that localises at the base of chondrocyte cilia. Development 2007;134(16): 2903-12.

[83] Akizu N, Silhavy JL, Rosti RO, Scott E, Fenstermaker AG, Schroth J, et al. Mutations in CSPP1 lead to classical Joubert syndrome. Am J Hum Genet 2014;94(1):80-6.

[84] Shaheen R, Shamseldin HE, Loucks CM, Seidahmed MZ, Ansari S, Ibrahim Khalil M, et al. Mutations in CSPP1, encoding a core centrosomal protein, cause a range of ciliopathy phenotypes in humans. Am J Hum Genet 2014;94(1):73-9.

[85] Rosenbaum JL, Witman GB. Intraflagellar transport. Nat Rev Mol Cell Biol 2002;3(11): 813-25.

[86] Cole DG, Snell WJ. SnapShot: Intraflagellar transport. Cell 2009;137(4):784-784.e1.

[87] Hao L, Efimenko E, Swoboda P, Scholey JM. The retrograde IFT machinery of C. elegans cilia: Two IFT dynein complexes? PloS one 2011;6(6):e20995.

[88] Ocbina PJ, Eggenschwiler JT, Moskowitz I, Anderson KV. Complex interactions between genes controlling trafficking in primary cilia. Nat Genet 2011;43(6):547-53.

[89] Ishikawa H, Marshall WF. Ciliogenesis: Building the cell's antenna. Nat Rev Mol Cell Biol 2011;12(4):222-34.

[90] Christensen ST, Pedersen LB, Schneider L, Satir P. Sensory cilia and integration of signal transduction in human health and disease. Traffic 2007;8(2):97-109.

[91] Veland IR, Awan A, Pedersen LB, Yoder BK, Christensen ST. Primary cilia and signaling pathways in mammalian development, health and disease. Nephron Physiol 2009;111(3):p39-53.

[92] Satir P, Pedersen LB, Christensen ST. The primary cilium at a glance. J Cell Sci 2010;123(Pt 4):499-503.

[93] Goetz SC, Anderson KV. The primary cilium: A signalling centre during vertebrate development. Nat Rev Genet 2010;11(5):331-44.

[94] Gerdes JM, Davis EE, Katsanis N. The vertebrate primary cilium in development, homeostasis, and disease. Cell 2009; 137(1):32-45.

[95] Kronenberg HM. Developmental regulation of the growth plate. Nature 2003;423(6937):332-6

[96] Rix S, Calmont A, Scambler PJ, Beales PL. An Ift80 mouse model of short rib polydactyly syndromes shows defects in hedgehog signalling without loss or malformation of cilia. Hum Mol Genet 2011;20(7):1306-14.

[97] Moyer JH, Lee-Tischler MJ, Kwon HY, Schrick JJ, Avner ED, Sweeney WE, et al. Candidate gene associated with a mutation causing recessive polycystic kidney disease in mice. Science 1994;264(5163):1329-33.

[98] Lin F, Hiesberger T, Cordes K, Sinclair AM, Goldstein LS, Somlo S, et al. Kidney-specific inactivation of the KIF3A subunit of kinesin-II inhibits renal ciliogenesis and produces polycystic kidney disease. Proc Natl Acad Sci U S A 2003;100(9):5286-91.

[99] Davenport JR, Watts AJ, Roper VC, Croyle MJ, van Groen $\mathrm{T}$, Wyss JM, et al. Disruption of intraflagellar transport in adult mice leads to obesity and slow-onset cystic kidney disease. Curr Biol 2007;17(18):1586-94.
[100] Jonassen JA, SanAgustin J, Baker SP, Pazour GJ. Disruption of IFT complex A causes cystic kidneys without mitotic spindle misorientation. J Am Soc Nephrol 2012;23(4):64151.

[101] Friedland-Little JM, Hoffmann AD, Ocbina PJ, Peterson MA, Bosman JD, Chen Y, et al. A novel murine allele of intraflagellar transport protein 172 causes a syndrome including VACTERL-like features with hydrocephalus. Hum Mol Genet 2011;20(19):3725-37.

[102] Simons M, Gloy J, Ganner A, Bullerkotte A, Bashkurov $\mathrm{M}$, Kronig $\mathrm{C}$, et al. Inversin, the gene product mutated in nephronophthisis type II, functions as a molecular switch between Wnt signaling pathways. Nat Genet 2005;37(5):537-43

[103] Lienkamp S, Ganner A, Walz G. Inversin, Wnt signaling and primary cilia. Differentiation 2012;83(2):S49-55.

[104] Pazour GJ, Rosenbaum JL. Intraflagellar transport and ciliadependent diseases. Trends Cell Biol 2002;12(12):551-5.

[105] Pazour GJ, Baker SA, Deane JA, Cole DG, Dickert BL, Rosenbaum JL, et al. The intraflagellar transport protein, IFT88, is essential for vertebrate photoreceptor assembly and maintenance. J Cell Biol 2002;157(1):103-13.

[106] Marszalek JR, Liu X, Roberts EA, Chui D, Marth JD, Williams DS, et al. Genetic evidence for selective transport of opsin and arrestin by kinesin-II in mammalian photoreceptors. Cell 2000;102(2):175-87.

[107] Sharoni E, Erez E, Chorev G, Dagan O, Vidne BA. Chest reconstruction in asphyxiating thoracic dystrophy. J Pediatr Surg 1998;33(10):1578-81.

[108] Todd DW, Tinguely SJ, Norberg WJ. A thoracic expansion technique for Jeune's asphyxiating thoracic dystrophy. J Pediatr Surg 1986;21(2):161-3.

[109] Davis JT, Ruberg RL, Leppink DM, McCoy KS, Wright CC Lateral thoracic expansion for Jeune's asphyxiating dystrophy: A new approach. Ann Thorac Surg 1995;60(3):694-6.

[110] Davis JT, Heistein JB, Castile RG, Adler B, Mutabagani $\mathrm{KH}$, Villalobos RE, et al. Lateral thoracic expansion for Jeune's syndrome: Midterm results. Ann Thorac Surg 2001;72(3):872-7; discussion 8

[111] Davis JT, Long FR, Adler BH, Castile RG, Weinstein S. Lateral thoracic expansion for Jeune syndrome: Evidence of rib healing and new bone formation. Ann Thorac Surg 2004;77(2):445-8.

[112] Renier JC, Larget-Piet L, Boasson M, Berthelot J, Fouillet JJ. Ellis-Van Creveld's chondro-ectodermic dysplasia: 2 cases in the same familly. Rev Rhum Mal Osteoartic 1975;42(6):417-22 (in French).

[113] da Silva EO, Janovitz D, de Albuquerque SC. Ellis-van Creveld syndrome: Report of 15 cases in an inbred kindred. J Med Genet 1980;17(5):349-56.

[114] Hennekam RC, Beemer FA, Gerards LJ, Cats BP. Thoracic pelvic phalangeal dystrophy (Jeune's syndrome). Tijdschr Kindergeneeskd 1983;51(3):95-100 (in Dutch).

[115] Labrune P, Fabre M, Trioche P, Estournet-Mathiaud B, Grangeponte MC, Rambaud C, et al. Jeune syndrome and liver disease: Report of three cases treated with ursodeoxycholic acid. Am J Med Genet 1999;87(4):324-8

[116] Camuglia JE, Greer RM, Welch L, Gole GA. Use of the electroretinogram in a paediatric hospital. J Clin Exp Ophthalmol 2011;39(6):506-12.

[117] Katsouras CS, Thomadakis C, Michalis LK. Cardiac Ellisvan Creveld syndrome. Int J Cardiol 2003;87(2-3):315-6. 